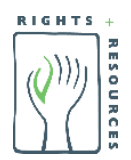

\title{
Uncertainty and Opportunity: \\ The Status of Forest Carbon Rights and Governance Frameworks in Over Half of the World's Tropical Forests
}

Rights and Resources Initiative

2715 M Street NW, Suite 300

Washington, DC 20007

P: +1 202.470.3900 | F: +1 202.944.3315

www.rightsandresources.org 
RRI is a global coalition consisting of 15 Partners, 7 Affiliated Networks, 14 International Fellows, and more than 150 collaborating international, regional, and community organizations dedicated to advancing the forestland and resource rights of Indigenous Peoples and local communities. RRI leverages the capacity and expertise of coalition members to promote secure local land and resource rights and catalyze progressive policy and market reforms.

RRI is coordinated by the Rights and Resources Group, a non-profit organization based in Washington, DC. For more information, please visit www.rightsandresources.org.

Partners
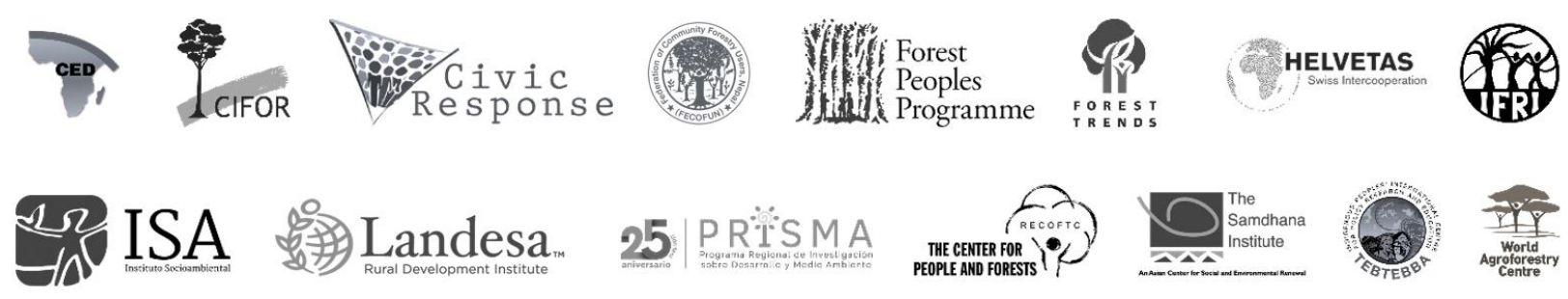

\section{Affiliated Networks}
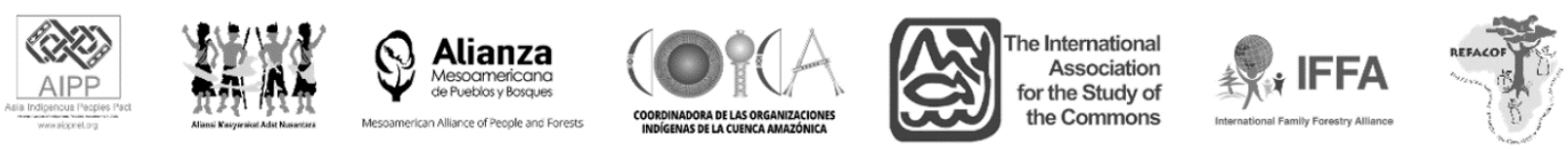

\section{Sponsors}

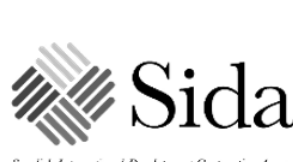
F. Schweizerische Eidgenossenschaí
Confécération suisse
Confeceraziun svizra
Swiss Agency for Development
and Cooperation SDC
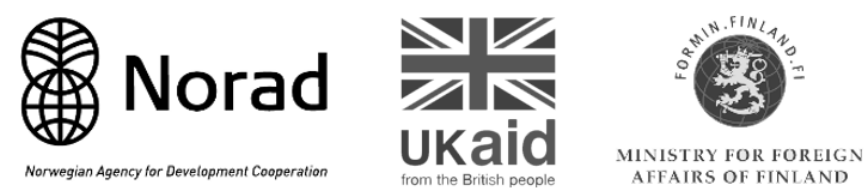

\section{8\% FORDFOUNDATION}

The views presented here are not necessarily shared by the agencies that have generously supported this work, or all of the Partners and Affiliated Networks of the RRI Coalition. This work is licensed under a Creative Commons Attribution License CC BY 4.0. 


\section{Contents}

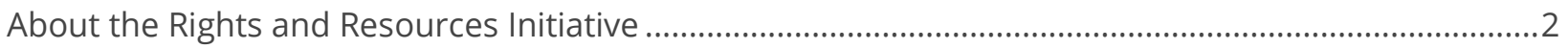

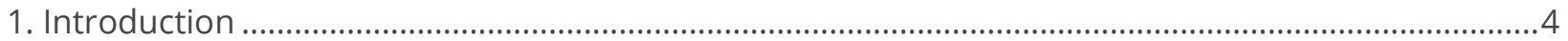

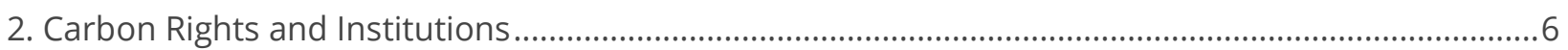

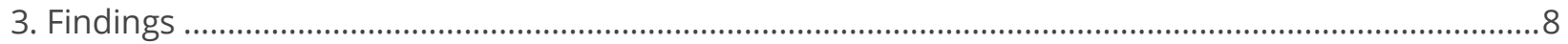

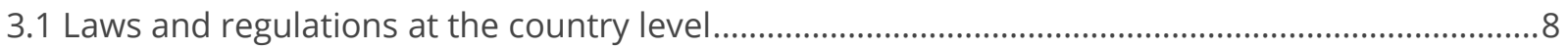

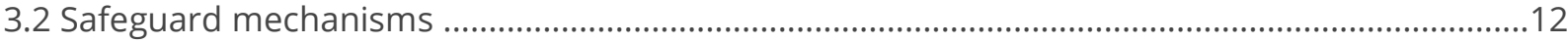

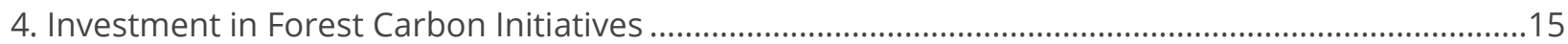

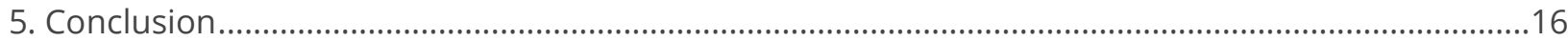

5.1 Moving toward a more just and climate-resilient future ..............................................................16

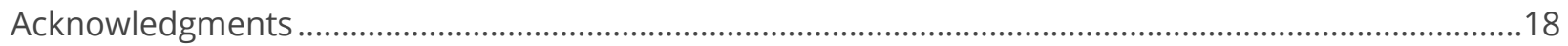

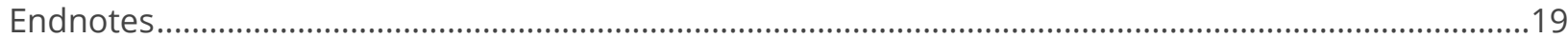




\section{Introduction}

Most of the world's remaining tropical forests lie in areas that are customarily managed and/or legally owned by Indigenous Peoples and local communities. ${ }^{1}$ In the context of climate change and global efforts to protect and enhance the capacity of forests to capture and store greenhouse gas emissions, the question of who owns the trees and the carbon stored therein is paramount. Clarifying this question is crucial, both for the future of the planet, and for up to 1.7 billion people worldwide who rely on forests for their livelihoods. ${ }^{2}$

Forests remove roughly 30 percent of human-caused greenhouse gas emissions from the atmosphere and have the potential to absorb even more. ${ }^{3}$ Unfortunately, annual rates of deforestation and forest degradation account for approximately 10 percent of total carbon emissions, ${ }^{4}$ and evidence suggests that the capacity of remaining forests to work as a net sink is rapidly being diminished. This creates a cascade of negative impacts that affect everything from rainfall to soil fertility, biodiversity, and the pursuit of sustainable development and poverty eradication. ${ }^{5}$

To counteract these trends, the international community adopted a global mechanism in 2007 to reduce deforestation and forest degradation in developing countries, and actively promote the sustainable management and conservation of forests and efforts to enhance forest carbon stocks (REDD+). While details of the mechanism are still being negotiated under the United Nations Framework Convention on Climate Change (UNFCCC), more than 50 developing countries have since initiated legal and institutional reforms at national and sub-national levels to reduce forest-related emissions in exchange for financial benefits. ${ }^{6}$

While details of the mechanism
are still being negotiated under
the United Nations Framework
Convention on Climate Change,
more than 50 developing
countries have since initiated
legal and institutional reforms at
national and sub-national levels
to reduce forest-related emissions
in exchange for financial benefits.

While details of the mechanism are still being negotiated under the United Nations Framework Convention on Climate Change, more than 50 developing countries have since initiated legal and institutional reforms at national and sub-national levels in exchange for financial benefits.

After more than 10 years of engagement, many countries are now moving forward on implementing national programs to reduce emissions from forestry and land use. These programs rely on measuring units of stored carbon to assess progress towards stated goals, and securing financial returns for achieving these goals through market-based instruments, bilateral agreements, or performance-based payment schemes. Consequently, clarifying who owns the carbon-and the land and forests containing that carbon-is essential to fulfilling the promise of results-based payments.

This brief presents a review of the nominal progress made in the national-level laws and regulations that govern the carbon trade and define the rights of parties -across a sample of 24 countries in Africa, Asia and Latin America. ${ }^{7}$ These countries collectively hold more than 50 percent of global tropical and subtropical forests. ${ }^{8}$ This brief also examines the design and establishment of safeguard 
mechanisms concerning benefit sharing, providing redress and resolution to disputes related to carbon-based schemes, and the operationalization of carbon registries for each of these countries.

Results show that there is still considerable ambiguity surrounding carbon rights and the legal basis for trading carbon credits, despite the fact that most of the countries analyzed are now involved in some form of carbon trade, either at the project level (i.e., activities carried out by for-profit or not-for-profit organizations on specific parcels of land) or at a sub-national or national scale (i.e., government-sponsored initiatives involving entire jurisdictions or nations). Defining carbon rights and establishing relevant governance institutions has been challenging for most of these countries. Among the primary reasons is that the legal recognition of Indigenous Peoples and local communities' rights to their forests and land remains ambiguous and unimplemented.

Following this introduction, we present a brief overview of the meaning and implications of carbon rights, carbon credits, and associated institutions in the context of the carbon trade (Section 2); present the key findings of the study (Section 3); and discuss trends in forest carbon financing and incentive mechanisms (Section 4). The study ends with a reminder of the necessary boundary conditions for a more just and equitable climate-resilient future.

Box 1: Key Findings

- 79 percent of countries (19/24) still do not have a national legal framework establishing and regulating carbon markets; Brazil, Costa Rica, Ecuador, Peru, and Vietnam have established such frameworks.

- Only four countries (Brazil, Costa Rica, Guatemala, and Peru) have explicitly defined carbon rights in national laws.

- 17 countries were considering draft laws and/or regulations to clarify carbon rights at the time of writing.

- $\quad$ Only three countries (Chile, Costa Rica, and Mexico) have designed both benefit-sharing mechanisms and feedback and grievance mechanisms (FGRMs), which are essential elements of functional REDD+projects and programs. No countries have operationalized their approach to benefit-sharing, and only two have implemented their FGRMs. 


\section{Carbon Rights and Institutions}

In the forestry and land use sector, carbon rights are premised on the idea that forest carbon stocks can be quantified and "sold" as an intangible asset (referred to as carbon credits, or verified emissions reductions units), ${ }^{9}$ typically measured in tons of carbon dioxide equivalent $\left(\mathrm{tCO}_{2} \mathrm{e}\right)$ emissions. The difference between the projected deforestation/degradation (without REDD+ actions) and the actual deforestation/degradation (with REDD+ actions) over that period of time amounts to the carbon credit. ${ }^{10}$ For reforestation/afforestation projects, carbon credits represent the amount of carbon sequestered in new growth.

To be recognized, carbon credits must be traceable back to a specific forest area within a given location or country. Because of this spatial dimension, questions of ownership; control; and use of the land, trees, and carbon associated with those forests are fundamental to the function and transparency of carbon-based payment mechanisms.

A carbon right can be defined in terms of which parties have the right to sell, trade, and purchase the carbon credit. This right can be tied to ownership or some degree of control over the trees that contain the carbon, or the land in particular. Alternatively, it may be considered a distinct proprietary interest separate from any underlying tenure right. When a credit is sold, it represents an obligation on behalf of the seller to ensure the preservation of that carbon for a duration established within the agreement with the buyer.

Relatedly, a carbon credit in the forestry and land use sector may refer to a unit that can be traded in the world's voluntary and/or compulsory markets, as well as measurable results achieved within the context of an agreement between buyers and project stakeholders. These types of carbon credits may also be defined within a bilateral agreement between a donor and a participating REDD+ country. In order to guarantee legal security, the rights and obligations of buyers and sellers must be defined in relevant laws, contracts, and project documents.

Another critical aspect of a carbon right is establishing who should receive the benefits of carbon credit sales. Financial benefits are typically allocated based on three categories of rights-holders: those who incurred implementation costs; those who incurred opportunity costs; and those who should reap the profits. ${ }^{11}$ These arrangements can be determined by contract, by policy, or by legislation. While laws can be used to ensure Indigenous Peoples and local communities, and especially women, have rights to access these benefits, as well as exercise their voice in how and why these benefits are allocated, application and enforcement necessarily requires political will and community-level access to information, and accountability and adjudication measures.

To strengthen country commitments to promote and respect the rights of vulnerable populations during the design and implementation of REDD+-related initiatives, the international community adopted the Cancun Agreement in 2010. Among other things, the safeguards contained in the Agreement highlight the need for: (i) "transparent and effective national forest governance structures;" (ii) "respect of the knowledge and rights of indigenous peoples and members of local 
communities;" and (iii) "full and effective participation of relevant stakeholders, in particular Indigenous Peoples and local communities."12 The Agreement also stresses the importance of developing and implementing gender-considerate national strategies and action plans. ${ }^{13}$ These safeguards are also reflected in and supplemented by the Convention on Biological Diversity (1992), which recognizes the importance of equitable benefit-sharing with Indigenous Peoples and local communities and the need for the full participation of women at all levels of policy-making in all initiatives that promote the conservation of biological diversity. ${ }^{14}$ The establishment of benefitsharing mechanisms, feedback and grievance redress mechanisms (FGRMs), and carbon registries are essential tools for ensuring implementation of these safeguards.

Benefit-sharing mechanisms help define which parties receive what benefits, and establish how these are to be transparently distributed. As previously mentioned in this section, benefit sharing is inherently linked to questions of tenure, such as control and use of lands and natural resources. For instance, questions of opportunity costs (to offset lost or displaced uses), the determination of which activities will be supported (management and control), and the distribution of profits are fraught with legal and ethical issues over who legitimately owns the rights to the carbon and the trees and forests wherein it is stocked. In the context of overlapping statutory and customary rights, these questions seldom yield clear-cut answers, especially in situations involving multiple owners (such as members of a community), or competing claimants.

To safeguard against potential infringements on rights, especially in the context of overlapping interests, most initiatives rely on the establishment of FGRMs. According to the World Bank's Forest Carbon Partnership Facility (FCPF) and UN-REDD Programme, the design of these institutions must be based on engagement and dialogue with stakeholders in order for them to be legitimate, accessible, predictable, equitable, transparent, and rights-compatible. ${ }^{15}$ The design of an FGRM must therefore be done in consultation with Indigenous Peoples and local communities, especially rural women, to ensure the relevance of these institutions to the most vulnerable actors.

Finally, carbon registries may also serve to safeguard rights by providing a verification system that can be checked against official cadasters and community-developed maps of their territories to assess whether the tenure rights of various stakeholders are being respected. Per FCPF directives, registries for carbon-based transactions must provide: (i) information on the holder of the "title" to the "emissions reductions" (credits derived from REDD+ activities); (ii) the geographical boundaries of the program or project; (iii) the scope of activities to be implemented; (iv) the quantity of carbon stored (carbon pools); and ( $v$ ) and the reference levels (the benchmarks for assessing performance). The FCPF also notes that the information should be publicly available (on the internet), and at the national level of the host country. ${ }^{16}$ In short, carbon registries help purchasers verify that the credits they acquire are not sold to more than one party. 


\section{Findings}

The methodology for this analysis is based on the methods used in RRI \& Ateneo de Manila University (2014), ${ }^{17}$ with additional input drawn from the Centre for International Forestry Research (2015) ${ }^{18}$ and Forest Trends' Ecosystem Marketplace Initiative. ${ }^{19}$ The analysis considers national-level laws and legally binding regulations ${ }^{20}$ in the following ten countries in Latin America: Brazil, Chile, Colombia, Costa Rica, Ecuador, Guatemala, Guyana, Mexico, Panama, and Peru; nine countries in Africa: Cameroon, the Democratic Republic of the Congo (DRC), Ethiopia, Ghana, Kenya, Liberia, Mozambique, the Republic of the Congo, and Uganda; and five countries in Asia: Cambodia, Indonesia, Lao People's Democratic Republic (Lao PDR), Nepal, and Vietnam. Reports produced by governments, international organizations, academics, and NGOs were also included in the review to contextualize and inform the interpretation of legally binding documents.

The questions guiding this analysis are drawn from concerns raised by indigenous groups, national civil society, academics, policymakers, government representatives, and funders of REDD+ initiatives. Monitoring and reporting inputs from these key constituencies were used across each of the countries assessed to validate observations drawn from other publicly available data sources. Further details on the methodology are provided in Annex 1.

\subsection{Laws and regulations at the country level}

In spite of increasing demand to finance reductions in emissions through projects and programs ${ }^{21}$, few countries have developed the legal and regulatory frameworks needed to support functional carbon trading schemes, though most have developed draft laws for further consideration.

Given that the majority of reviewed countries have either sanctioned market-based REDD+ projects or are engaged in negotiations with a dedicated funding mechanism to secure long term REDD+ financing to reduce emissions, limited country progress in the formalization of essential legal instruments is concerning (see Table 1 below). Currently, only $\mathbf{5}$ of the $\mathbf{2 4}$ countries assessed (Brazil, Costa Rica, Ecuador, Peru, and Vietnam) have established national legal frameworks to regulate their trade in carbon, and only 4 (Brazil, Costa Rica, Guatemala, and Peru) have legally defined carbon rights. While modest, these developments represent an improvement since the 2014 study by RRI \& Ateneo de Manila University, wherein none of the 23 countries assessed at the time (including Brazil, Peru, and Vietnam) had national legal frameworks to support trade in carbon. ${ }^{22}$ Moreover, at least 17 of the countries covered in this analysis were considering draft laws and/or regulations on carbon rights at the time of writing, ${ }^{23}$ and if stated political intentions are maintained and supported, some of these could strengthen community land and forest rights (see Opportunities for Equitable Reforms in Box 2).

Of the five countries with legal frameworks regulating the carbon trade, Ecuador is the only jurisdiction to prohibit private ownership of environmental services (including carbon sequestration). ${ }^{24}$ While the production, provision, and use of such services will be regulated by 
government, they are not susceptible to appropriation, ${ }^{25}$ and therefore not liable to be traded in any market mechanism. ${ }^{26}$

Overall, only four countries explicitly define carbon rights in their national laws (Brazil, Costa Rica, Guatemala, and Peru), and three of these associate such rights with legally-recognized land titles. As such, a landowner or other legally-recognized concession holder may lawfully claim the rights to the carbon contained within their parcel. In Brazil however, carbon rights are vested in the legallyrecognized owner of the trees holding said carbon, per the country's legal interpretation of forest rights.

Seven other countries-DRC, Ecuador, Kenya, Indonesia, Mexico, Nepal, and Vietnam-mention carbon rights in relevant national laws or regulations but proposed definitions were either ambiguous, not fully defined, undergoing legal challenges, and/or subject to additional laws or regulations that have yet to be adopted. In Kenya, the law does not specifically mention carbon, but laws regulating property rights and benefits from forest ecosystems could be interpreted as providing a basis for carbon rights. Four of the seven countries have laws suggesting that the state exercises some degree of ownership over carbon credits, potentially delinking rights to carbon from rights to land or other natural resources. ${ }^{27}$

Table 1: Status of carbon rights in national-level legislation \& the investments in carbon credits

\begin{tabular}{|c|c|c|c|}
\hline Number of countries that have & Yes & No & Unclear \\
\hline Established a national legal framework for carbon trade & 5 & 18 & 1 \\
\hline Defined carbon rights in national laws or regulations & 4 & 13 & 7 \\
\hline $\begin{array}{l}\text { Planned or implemented forest carbon projects (voluntary } \\
\text { market) }\end{array}$ & 20 & 3 & 1 \\
\hline $\begin{array}{l}\text { Donor-led payment agreements for emissions reductions } \\
\text { (Norway, Early Movers, or Amazon Fund) }\end{array}$ & 8 & 16 & 0 \\
\hline $\begin{array}{l}\text { Ongoing negotiations with the BioCarbon Fund or Carbon } \\
\text { Fund }\end{array}$ & 16 & 8 & 0 \\
\hline
\end{tabular}

\section{Box 2: Opportunities for Equitable Reforms}

At least three countries are considering reforms that would clarify both carbon rights and the rights of Indigenous Peoples and local communities to their lands and forests.

Ethiopia: Participatory Forest Management is a key pillar of Ethiopia's REDD+ strategy, which calls for "community forest ownership under the new Federal Forest Proclamation." 28 With its adoption slated for 2018, the new Forest Proclamation is expected to also clarify carbon rights. ${ }^{29}$ 
Kenya: The Natural Resources Benefit Sharing Bill, which has been stalled in the Senate since 2014, would establish the legal basis for allocating benefits to stakeholders (including local communities) affected by investments in various natural resource sectors, including forestry. The Parliament is also deliberating a Climate Change Finance Policy that should help regulate the carbon trade in the future.

The Republic of the Congo: A new forest code is expected to pass in $2018,{ }^{30}$ which is expected to establish new legal frameworks recognizing community-based tenure, and would also allow the state to generate carbon credits, or authorize "any natural person or legal entity, including local communities and indigenous peoples"31 to generate them.

\subsubsection{Risks of ambiguous and unimplemented rights}

Poorly-defined land and carbon rights are a major source of risk for the realization of equitable and sustainable emission reductions, and a critical barrier to securing Indigenous Peoples' and local communities' land and resource rights.

In the absence of clear legislative definitions of carbon rights or mechanisms to trade in carbon credits, project designers must use informed interpretations of existing resource laws and regulations from other sectors as "proxies." This process is time consuming and expensive, making it difficult for many small-scale projects to access markets. ${ }^{32}$ Furthermore, the likely introduction of new carbon-specific laws, regulations, and policies can be a source of risk for existing market-based projects that previously relied on proxy laws and regulations. The introduction of new regimes can render previous interpretations irrelevant or unlawful (See Box 3 on Mexico, Ecuador, Nepal, and Indonesia).

Moreover, undefined or ambiguously-defined carbon rights can pose significant risks to Indigenous Peoples' and local communities' efforts to secure their legitimate, but not yet formally recognized, land and resource rights. ${ }^{33}$ At the same time, attempts to explicitly define carbon rights can also yield negative consequences for Indigenous Peoples and local communities, especially in situations where their customary rights are not legally recognized-a situation that afflicts most of the countries in this study. ${ }^{34}$ When local peoples' tenure rights are not formally recognized or are insecure in practice, financial flows are more likely to go to governments, concessionaires, and local elites than to rural communities, thus creating further incentives to limit the prospects of reforms that could jeopardize rent-seeking opportunities for more powerful actors.

\section{In contexts where unclear and contested tenure rights are identified as a key driver of} deforestation (13/24 countries in this review), attributing carbon rights without first clarifying and securing community land and resource rights is likely to exacerbate existing trends and tensions. Despite noted intentions to clarify the tenure rights of Indigenous Peoples and local communities in at least 21 of the 24 national REDD+ strategies examined, evidence of planned or ongoing tenure reforms remains weak. This is problematic on a number of fronts. In addition to the failure to address a key driver of deforestation, the lack of clear tenure rights for 
rural communities also undermines their ability to meaningfully engage in relevant decision-making fora, or rightfully receive both carbon and non-carbon benefits for contributions made towards the management and conservation of forest carbon stocks.

On the other hand, efforts to delink carbon rights from existing land and resource titles or claims tend to result in state ownership of those rights, which creates its own challenges. Vesting decisionmaking authority and benefits in the state can infringe upon the rights of others (individuals or communities) to access legally-owned or customarily-managed forests. Government ownership is associated with top-down accountability mechanisms that reduce the need for consultation or compensation when there is a potential for lost livelihoods. ${ }^{35}$ Ultimately, limited stakeholder buy-in may undermine program goals altogether.

For its part, the Green Climate Fund appears to neglect the possibility that carbon rights, at the country level, could be vested in parties other than the state. While recognizing that "legal frameworks in many REDD+ host countries [do] not currently provide for tradeable carbon units" and that existing laws often fail to detail "the rights and privileges the state has to such carbon," the focus is placed on the challenge of retiring results and the risk of double counting, not on the possibility of infringements on the land and resource rights of Indigenous Peoples and local communities. ${ }^{36}$ Fortunately, the newly-adopted Indigenous Peoples' Policy provides critical assurances for the protection of statutory and customary rights of Indigenous Peoples and local communities, including their rights to land, resources, and associated project benefits for all GCFsupported investments-paving the way for more equitable emission-reduction schemes. ${ }^{37}$

\section{Box 3: Uncertainty in Mexico, Ecuador, Nepal, and Indonesia}

There is an ongoing debate in Mexico regarding who owns the rights over avoided emissions from deforestation and forest degradation. Avoided emissions were initially interpreted as an environmental service that can be commodified, based on the 2003 Law for Sustainable Forest Development (LGDFS), the 2015 Draft of the National REDD+ Strategy, and the 2015 rules to register forest carbon projects. However, in Mexico's 2016 Emissions Reduction Program Documents (ERPD), the government claimed ownership of the credits resulting from reduced emissions. It emphasized that the ownership of emissions reductions is not connected with underlying tenure rights, and cannot be awarded to smallholders, indigenous communidades, or ejidos. The ERPD also notes that according to Article 481 of the Mexican Penal Code, deforestation is a crime punishable by the State, and therefore the State cannot reward conduct (such as the avoidance of tree cutting associated with a carbon offset scheme) which amounts to simple compliance with existing legal prohibitions. ${ }^{38}$ Given this legal confusion, a 2016 Technical Assessment of Mexico's ERPD concluded that Mexico did not demonstrate that it would be able to transfer the Carbon Fund Title to Emissions Reductions (ERs) while respecting the land and resource tenure rights of potential rights holders, including Indigenous Peoples. ${ }^{39}$

In Ecuador, Article 74 of the Constitution prohibits private ownership of environmental services. ${ }^{40}$ However, Ecuador's 2016 National Action Plan outlines the goal to protect the collective rights of all Ecuadoreans to benefit from natural resources and provides that the state will establish a framework to 
regulate the use and benefit of environmental services. ${ }^{41}$ Since this framework has yet to be passed, forest carbon projects that trade in voluntary markets are not permissible, and the national REDD+ policy focuses exclusively on the causes of deforestation. Furthermore, Article 17 of the 2016 Ministerial Agreement 116 established that all negotiations for forest carbon credits must go through the REDD+ National Authority. There were attempts by project developers to establish at least two small-scale projects in Ecuador, but they were unable to obtain certification to sell on the voluntary market. ${ }^{42}$

In 2015, Nepal passed a new constitution that explicitly establishes "carbon services" as one of the issues over which the federal government has jurisdictional authority. The 2016 amendment to the 1993 Forest Act identifies that the Ministry of Forest and Soil Conservation has authority to make arrangements for the management, utilization, and benefit sharing of environmental services, including forest carbon stocks. ${ }^{43}$ Amendments to the Forest Regulations are still required to define the legal nature and title of transfer for carbon credits. However, the Emissions-Reduction Project Idea Note submitted by the Nepalese government to the FCPF in 2017 proposes that: "the title of carbon emission rests with the person (biological and legal) who contributes to reducing emissions. However, the individual person cannot transfer the emission title like other private property or tangible forest products, such as timber and medicinal herbs, because the Federal Government has power over carbon services as well as the land ownership of national forests." 44 It goes on to state that "The Federal Government (...) can transfer title of carbon emission to any entity." Following this legal and regulatory confusion, the sole (community-based) carbon project that had officially registered with the government's REDD+ cell discontinued attempts to sell credits in 2017.45

Risks to existing projects have also been identified in Indonesia as the government is attempting to restructure its approach to REDD+ from a "market-based instrument to become more of a public-funding instrument, which may substantially reconfigure carbon tenure arrangements in the country." ${ }^{46}$ This change in approach also seems to be based on the government's desire to count achieved emissions reductions toward national targets so as to comply with the Paris Agreement, which may end up meaning that there will be limits on the amount of credits that can be sold to international buyers. ${ }^{47}$ Furthermore, while social-forestry based REDD+ projects seem to have a clearer legal pathway to trade in carbon, the current legal definitions of carbon rights and the basis for trade on a commercial scale are unclear and contested. ${ }^{48}$

\subsection{Safeguard mechanisms}

\section{Few countries have developed the institutional safeguards needed to support transparent and equitable emission reduction programs, despite years of readiness investments.}

The basic elements of the REDD+ governance structure are either missing or inoperative in most of the reviewed countries. As discussed in Section 2, the establishment of effective benefit-sharing mechanisms, grievance redress mechanisms, and registries are essential pieces of the REDD+ architecture, providing a foundation for the pursuit of transparent and equitable performancebased payments and/or participation in voluntary markets. Yet most countries lack the means to trace the source of carbon credits or ensure that the rights of vulnerable populations are respected. As of the end of 2017, only three countries (Chile, Costa Rica, and Mexico) have designed both 
benefit-sharing mechanisms and FGRMs, though none have operationalized their approach to benefit-sharing and only two have functional FGRMs. Similarly, only five countries have developed carbon registries, but none are considered operational at this stage (see Table 2).

Table 2: Establishment of safeguard institutions

\begin{tabular}{|l|l|l|l|}
\hline Number of countries that have & Yes & No & Unclear \\
\hline Designed Benefit-Sharing Mechanisms & 4 & 13 & 7 \\
\hline $\begin{array}{l}\text { Operationalized Benefit-Sharing Mechanisms } \\
\text { Designed Feedback and Grievance Redress Mechanisms }\end{array}$ & 0 & 21 & 3 \\
\hline $\begin{array}{l}\text { Operationalized Feedback and Grievance Redress } \\
\text { Mechanisms }\end{array}$ & 2 & 13 & 3 \\
\hline $\begin{array}{l}\text { Operationalized Carbon Registries } \\
\text { Opention }\end{array}$ & 0 & 19 & 5
\end{tabular}

\subsubsection{Benefit-sharing mechanisms}

Commitments to develop operational and legally sanctioned benefit-sharing mechanisms remains a struggle for most countries. To date, only four countries (17 percent) have designed clear mechanisms, none of which could be verified as operational. Amongst these, Costa Rica stands out as the only country to have both clearly defined carbon rights and a national benefit-sharing mechanism. Several more countries are in advanced stages of designing their approach to benefit sharing, and some are expected to be finalized in 2018. Whether these are developed in consultation with and/or endorsed by Indigenous Peoples and local communities remains to be seen.

National benefit-sharing mechanisms are not required for the establishment of project-based forest carbon projects, but balancing effectiveness and equity is a struggle for many project-level initiatives. ${ }^{49}$ While some project developers explicitly seek out certification based on community rights and benefits (such as Plan Vivo, SOCIALCARBON, and CCB), Forest Trends found that in 2016, only 50 percent of forestry projects reported having community benefits, ${ }^{50}$ such as access to education and capacity building support, though the vast majority (98\%) reported providing some form of employment opportunity.

\subsubsection{Feedback and grievance redress mechanisms}

As the Joint FCPF and UN-REDD Guidance Note states, feedback and grievance mechanisms "need to be available to REDD+ stakeholders from the earliest stages of Readiness Preparation Proposal (RPP) implementation." 51 These institutions are essential safeguards for indigenous and local communities, serving as "early warning mechanisms" for infringements on their rights.

Most of the countries reviewed are several years into their R-PPs and actively negotiating purchasing agreements with the Carbon Fund and BioCarbon Fund, and/or have established bilateral agreements with emissions reductions identified as deliverables in exchange for receiving 
payments. As such, it is concerning to note that only one-third of the countries reviewed have designed grievance mechanisms, and that these are operationally ready in only two countries (Costa Rica and Mexico).

Most countries integrate FGRM into the existing judicial systems. While diminishing the need for costly and overly complex parallel structures, existing legal frameworks seldom meet the criteria of accessibility, legitimacy, and predictability, as required under UN-REDD and FCPF guidance. ${ }^{52}$ Only Mozambique and Costa Rica developed distinct legal structures to address carbon-related grievances.

An operational FGRM is required for projects certified by Plan Vivo ${ }^{53}$ and the pursuit of jurisdictional and nested REDD+ under the Voluntary Carbon Standard (VCS). ${ }^{54}$ While the Gold Standard ${ }^{55}$ and the VCS ${ }^{56}$ call for project-level mechanisms that can receive and incorporate feedback, both lack language on redress for aggrieved parties. As such, in countries where a national FGRM is absent, these certification schemes provide some level of assurance to stakeholders, but further analysis would be required to see whether they conform to UN-REDD and FCPF guidelines. Clearly, national FGRM would lower transaction costs and provide greater assurance in terms of consistency and predictability for any REDD+ project.

\subsubsection{Carbon registry}

Carbon registries provide transparency of transactions-ensuring that sold credits are not repurposed for others and that specific credits are linked to the underlying rights of producers. However, only five of the countries reviewed have registries, and none could be verified as being operational or compliant with FCPF guidelines.

While national registries are less of a requirement for countries with project-based approaches only, due to the use of private registries for voluntary certification schemes (e.g., Gold Standard, VCS, and Plan Vivo), such registries will become essential as countries engage in jurisdictional- and nationallevel schemes requiring the "nesting" of small- and large-scale projects. 


\section{Investment in Forest Carbon Initiatives}

\section{By affecting the incentives national governments face, voluntary markets and international climate investments also influence country recognition of indigenous and community land and forest rights.}

Small-scale forest carbon projects are now being pursued or are already trading in voluntary markets in 87 percent (21/24) of the countries featured in this analysis, ${ }^{57}$ though three-quarters of these are concentrated in only 6 countries (Colombia, Peru, Kenya, Brazil, Indonesia, and Uganda). ${ }^{58}$

Likewise, donor institutions associated with the REDD+ Early Movers Program (Norway, the United Kingdom, and Germany) and Norway's own bilateral agreements have pledged a cumulative US\$2.9 billion in payments for REDD+, destined for eight countries. ${ }^{59}$ While some of these funds are earmarked for REDD+ readiness, a substantial proportion are for emissions reductions. As of 2017, these donors have disbursed US\$218 million to Brazil, Guyana, and Colombia, although only part of the payments to Brazil and Colombia were for achieved emissions reductions. ${ }^{60}$ In Brazil, the Amazon Fund has disbursed 94 percent of the US\$1.2 billion that was pledged. ${ }^{61}$

Dedicated climate funds, on the other hand, have yet to disburse any funds, either for planned or achieved emissions reductions. As of 2017, the FCPF Carbon Fund had signed letters of intent with 19 countries ( 14 from this study's sample of countries) ${ }^{62}$ and pledged up to US\$686 million. Emissions reduction payment agreements (ERPAs) are expected to be signed shortly with Chile, DRC, and Ghana, and the Carbon Fund is in advanced negotiations with Costa Rica, Mexico, and the Republic of the Congo. ${ }^{63}$ The BioCarbon Fund has similarly signed letters of intent with three countries (Colombia, Ethiopia, and Zambia), ${ }^{64}$ pledging up to US\$130 million in Purchase Agreements that are expected to be approved with all three in 2018. Lastly, in October 2017, the Green Climate Fund pledged US $\$ 500$ million for results-based payments and had begun to solicit applications from countries. ${ }^{65}$

While forest carbon financing structures are designed to stimulate policies and actions in favor of forest conservation and restoration, they also affect the incentives governments face in terms of determining how benefits are distributed and to whom. Evidence to date suggests that governments are overwhelmingly reluctant to make Indigenous Peoples, local communities, and rural womenwho are principally affected by REDD+ policies and interventions-key recipients of carbon and noncarbon benefits. ${ }^{66}$ Collectively however, governments, donors, investors, and international finance institutions can change the situation, including the repercussions that emerging global investments will have on the rights and livelihoods of forest-dependent communities, especially Indigenous Peoples and rural women. 


\section{Conclusion}

After more than a decade of engagement on the concept of payment for ecosystem services and performance-based payment schemes, commitments to clarify the meaning and legal implications of carbon rights remain largely unfulfilled. While some countries are developing legal frameworks to support trade in forest carbon credits, the creation of a truly global, transparent, and equitable carbon offset mechanism is unlikely to emerge in the near to midfuture.

Of the 24 countries reviewed in this analysis, only Costa Rica has: (i) established a legal framework to trade carbon; (ii) explicitly defined carbon rights; (iii) designed a benefit-sharing mechanism; and (iv) established a fully-functional FGRM. And even with this progress, Costa Rica still has not operationalized its benefit-sharing mechanism, nor has it developed a carbon registry.

The gaps identified in this report are problematic, and their presence adds uncertainty, costs, and risks for Indigenous Peoples, local communities, and rural women, as well as for governments, investors, and project developers alike. While the threats to community rights and livelihoods are considerable, limited country progress in the development of requisite legal instruments also highlights opportunities for change, and the advancement of rights-based approaches that prioritize Indigenous Peoples, local communities, and rural women more specifically.

\subsection{Moving toward a more just and climate-resilient future}

Responsibilities for strengthening the positive impacts of forest-related emission reduction schemes are widely shared. However, by setting the terms and conditions of engagement on REDD+ processes, national governments and international climate financing institutions and mechanisms have a decisive role to play in ensuring that climate actions respect, promote, and consider the rights of Indigenous Peoples, local communities, and women, and are pursued on the basis of equity and in the context of sustainable development and efforts to eradicate poverty-per the Paris Agreement. To achieve such ends:

\section{Governments in participating REDD+ countries should:}

1. Prioritize the development of the legal and regulatory frameworks needed to support emission reduction projects and programs, including the legal basis for trade in carbon and the distribution of both carbon and non-carbon benefits to all stakeholders, including Indigenous Peoples, local communities, and rural women;

2. Prioritize investments in implementing the legal recognition of Indigenous Peoples', local communities', and rural women's land and forest rights, including their rights to the trees and carbon stored therein;

3. Finalize the development of key REDD+ governance institutions related to social and environmental safeguards, benefit sharing, and feedback and grievance redress mechanisms in 
collaboration with-and the free, prior and informed consent of-Indigenous Peoples, local communities, and rural women;

\section{Climate financing institutions and mechanisms should:}

1. Strengthen performance-based principles by conditioning financial disbursements for emission reductions schemes to countries where key readiness milestones have been reached, including:

a. Legal frameworks to support national- and project-level trade in carbon are adopted;

b. Carbon rights are clearly and transparently defined;

c. Benefit sharing plans, grievance redress mechanisms, and carbon registries are operational, and are accessible to and designed in collaboration with Indigenous Peoples, local communities, and rural women, and with their free, prior, and informed consent.

2. Prioritize purchasing agreements with countries that have already demonstrated a commitment to clarifying and securing the tenure rights of Indigenous Peoples, local communities, and rural women. 


\section{Acknowledgments}

This report is the result of a broad collaboration between primary authors-Alexandre CorriveauBourque, Fernanda Almeida, and Alain Frechette-, RRI staff, independent consultants and national experts. The project was supervised by Alain Frechette, Stephanie Keene, and Chloe Ginsburg, with data collection support by Ana Clara Simões, Amanda Duque dos Santos, and Sofia Neto Oliveira. Data on investments was provided by Kelley Hamrick and Brian Schaap, and information on carbon markets was provided by Chris Stephenson and Sam Hoffer.

The authors would like to thank the following country reviewers for their time, energy, and knowledge: Caroline Almeida Souza; Keila Karoline Magalhães Marques; Ana Paula de Souza Silva; Donal Yeang; René Ngamabou Siwe; Alberto Moya Mena; Juan Pablo Castro; Marianella Feoli; German Obando; William Alpízar Zúñiga; Augustin Mpoyi; Kamathe Katsongo; Anonymous; Darragh Conway; Luiz Guilhermo Ramirez; Mark Bynoe; Yosef Arihadi; Daju Resosudarmo; Dorothea Pio; Ahmad Kusworo; Emmanuel Emorut Ekakoro; Robert Kibugi; Akiko Inoguchi; Mike Dwyer; Ana Carolina Izaguirre Corzo; Juan Carlos Carillo; Leticia Gutierrez Lorandi; Francisco Sambo; Meena Kunwar; Emilio Mariscal; Javier Mateo-Vega; Charlie Langan; and Bill Farmer. 


\section{Endnotes}

${ }^{1}$ RRI. 2014. What Future for Reform? Progress and slowdown in forest tenure reform since 2002. Washington DC: Rights and Resources Initiative.

2 igh Level Panel of Experts on Food Security and Nutrition. 2017. Sustainable Forestry for Food Security and Nutrition. HLPE Report 11, FAO, Rome. Available at: http://www.fao.org/3/a-i7395e.pdf; Chao, Sophie. 2012. Forest Peoples: Numbers Across the World. Forest Peoples Programme, Moreton-in-Marsh.

3 Le Quéré, C. et al. 2016. Global carbon budget. Earth Systems Science Data. 8: 605-649

4 Union of Concerned Scientists. 2013. Measuring the Role of Deforestation in Global Warming. Last revised date: 09 December, 2013. https://www.ucsusa.org/global-warming/solutions/stop-deforestation/deforestationglobal-warming-carbon-emissions.html\#.Wk5EXt-nGM8.

${ }^{5}$ Houghton, R. A., Birdsey, R. A. Nassikas, A., and D. McGlinchey. 2017. Forests and Land Use: Undervalued Assets for Global Climate Stabilization. Policy Brief. Falmouth: Woods Hole Research Center. Baccini, A., Walker, W., Carlvalho, L. Farina, M., Sulla-Menashe, D and R.A. Houghton. 2017. Tropical forests are a net carbon source based on aboveground measurements of gain and loss. Science. 358.

${ }^{6}$ For a detailed history of the origins and subsequent development of the REDD+ mechanism within the context of the UNFCCC, see https://theredddesk.org/what-redd.

${ }^{7}$ The countries covered within this study include in Latin America: Brazil, Chile, Colombia, Costa Rica, Ecuador, Guatemala, Guyana, Mexico, Panama, and Peru; in Africa: Cameroon, Democratic Republic of the Congo, Ethiopia, Ghana, Kenya, Liberia, Mozambique, Republic of the Congo, and Uganda; and in Asia: Cambodia, Indonesia, Lao People's Democratic Republic, Nepal, and Vietnam.

${ }^{8}$ FAO. 2015. "1. Forest Area and Characteristics." Downloaded from FAO. 2018. "Global Forest Resources Assessments." Accessed February 8, 2018. Available at: http://www.fao.org/forest-resourcesassessment/explore-data/flude/en/.

${ }^{9}$ For the sake of simplicity, and the fact that the countries reviewed had both REDD+ and deforestation / afforestation projects, the term carbon credit will be used throughout this brief, unless a direct citation is used. 10 This approach has been criticized in that it de-values the actions of actors who already demonstrate good stewardship of the forests they own or control, especially Indigenous Peoples and other local communities, since their existing activities would not be able to demonstrate "additionality".

11 Peskett. L. 2010. Benefit Sharing in REDD+: Exploring the Implications for Poor and Vulnerable People. Washington DC: The World Bank.

12 UNFCC. 2010. Appendix 1. Report of the Conference of the Parties on its sixteenth session, held in Cancun from 29 November to 10 December 2010. New York: United Nations Framework Convention on Climate Change.

13 UNFCC. 2010. Paragraph 72, as cross-referenced by Appendix 1 para 2(d).

14 United Nations. 1992. Convention on Biological Diversity. p 1-2

15 UN REDD \& FCPF. 2015. Joint FCPF/UN-REDD Programme Guidance Note for REDD+ Countries: Establishing and Strengthening Grievance Redress Mechanisms. 
${ }^{16}$ FCPF. 2013. Carbon Fund Methodological Framework. Washington DC: Forest Carbon Partnership Facility. p. 26-27.

17 RRI \& Ateneo de Manila University. 2014. Status of Forest Carbon Rights and Implications for Communities, the Carbon Trade, and REDD+ Investments. Washington DC: Rights and Resources Initiative.

18 Loft, L., Ravikumar, A., Gebara, M.F. Thuy Pham, T., Resosidarmo, I.A.P., Assembe, S., Tovar, J.G., Mwangi, E., and K. Andersson. 2015. Taking Stock of Carbon Rights in REDD+ Candidate Countries: Concept Meets Reality. Forests. 6: 1031-1060.

19 Forest Trends' Ecosystem Marketplace.

${ }^{20}$ In some federalized countries like Ethiopia and Brazil, there may be subnational laws that play a role in regulating the carbon trade, and defining carbon rights. These laws and regulations are outside the scope of this assessment.

${ }^{21}$ Finance in this report relates only to payment for performance, not readiness funding.

22 RRI \& Ateneo de Manila University. 2014. Status of Forest Carbon Rights and Implications for Communities, the Carbon Trade, and REDD+ Investments, p. 3.; Changes in Brazil and Peru are the result of recent legal reforms, while Vietnam was identified following the availability of more recent data. Specifically, noted reforms include the issue of decree n. 8576/2015, establishing the National Commission for the Reduction of Greenhouse Gas Emissions from Deforestation and Forest Degradation, Conservation of forest carbon stocks, sustainable management of forests, and forest carbon stocks increase - REDD+ and the approval of the National REDD+ strategy. It is worth noting that Brazil's legal framework establishing rules and regulations for carbon trade exists but is still highly insufficient to establish a completely functioning carbon market. See Ministério do Meio Ambiente. 2016. ENREDD+. Estratégia Nacional para Redução das Emissões Provenientes do Desmatamento e da Degradação Florestal, Conservação dos Estoques de Carbono Florestal, Manejo Sustentável de Florestas e Aumento de Estoques de Carbono Florestal. ; Presidência da República Federativa do Brasil. 2015. Decreto n. 8576 de 2015. Institui a Comissão Nacional para Redução das Emissões de Gases de Efeito Estufa Provenientes do Desmatamento e da Degradação Florestal, Conservação dos Estoques de Carbono Florestal, Manejo Sustentável de Florestas e Aumento de Estoques de Carbono Florestal - REDD+.

23 It was not always possible to obtain copies of the draft laws, so proxy reports had to be used when available to understand their potential content.

${ }^{24}$ Carbon is not explicitly listed, but is widely interpreted as being included.

${ }^{25}$ Article 74. Constitución de la República del Ecuador. 2008. This article establishes that "the people, communities and indigenous groups have the right to benefit from the environment and the natural richness afforded by well-being. Environmental services are not susceptible to appropriation; their production, provision and use will be regulated by the National Government."

${ }^{26}$ Ministerio del Ambiente. 2016. Plan de Acción REDD+ Ecuador. Bosques para el Buen Vivir. (2016-2025). p. 9394.

27 An official government opinion can come through the Programme Documents submitted to the Carbon Fund or BioCarbon Fund, since it demonstrates how some of the relevant parties in government intend to interpret the law to receive payments for emissions reductions in future agreements with these financing institutions.

${ }^{28}$ National REDD+ Secretariat. 2016. National REDD+ Strategy. Ministry of Environment, Forest and Climate Change: Federal Democratic Republic of Ethiopia. p 41. 
29 National REDD+ Secretariat. 2017. R-Package: Readiness Progress and Multi-Stakeholder Self-Assessment Report of Ethiopia. Ministry of Environment, Forest and Climate Change: Federal Democratic Republic of Ethiopia.

30 Anonymous. 2017. Communications with the Rights and Resources Initiative.

${ }^{31}$ FCPF. 2017. Emissions Reduction Program in Sangha and Likouala, Republic of the Congo. Washington DC. Forest Carbon Partnership Facility Carbon Fund. p 87.

32 Chapman, S. and M. Wilder. 2013. Fostering REDD+ Investment through effective legal frameworks: Lessons from the development of early forest carbon projects. Carbon \& Climate Law Review. 7(1): 43-53.

33 Sarmiento Barletti, J. P and A.M. Larson. 2017. Rights abuse allegations in the context of REDD+ readiness and implementation: A preliminary review and proposal for moving forward. CIFOR Infobrief No. 190. Bogor: Center for International Forestry Research; Larson, A. 2010. Forest tenure reform in the age of climate change: Lessons for REDD+. Global Environmental Change. 21: 540-549.

34 RRI. 2014. What Future for Reform? Progress and slowdown in forest tenure reform since 2002. Washington DC. Rights and Resources Initiative. RRI. 2017. Power and Potential: A Comparative Analysis of National Laws and Regulations Concerning Women' Rights to Community Forests. Washington DC. Rights and Resources Initiative.

35 Angelsen. A. 2017. Walking the REDD+ Line: Insights From CIFOR's REDD+ Global Comparative Study. (Power point presentation). Bogor: Center for International Forestry Research.

${ }^{36}$ Green Climate Fund. 2017. Request for proposals for the pilot programme for REDD- plus results-based payments. GCF/B.18/06. Paragraphs 32 and 33, as well as footnote 8.

${ }^{37}$ Green Climate Fund. 2018. GCF Indigenous Peoples Policy. GCF/B.19/05.

${ }^{38}$ Forest Carbon Partnership Facility. 2016. Emission Reductions Program Document (ERPD). Mexico. p. 4, 262 and 262,238 and 241.

${ }^{39}$ Forest Carbon Partnership. 2016. Technical Assessment of Final ER-DP Mexico. p. 49-53.

${ }^{40}$ Article 74. Constitución de la República del Ecuador. 2008.

${ }^{41}$ Ministerio del Ambiente. 2016. Plan de Acción REDD+ Ecuador. Bosques para el Buen Vivir. (2016-2025). p. 93.

42 Moull, K., and J. Olander. 2016. Ecuador. Seguimiento al Financiamiento para REDD+. Período 2013-2014. Informe nacional REDDX. Washington DC: Forest Trends.

43 FCPF. 2017. Emission Reduction Program Document - People and Forests - A sustainable forest managementbased emission reduction program in the Terai Arc Landscape, Nepal. p.85 \& 182-184.

${ }^{44}$ In Nepal, all community-controlled forests are legally owned by the state.

45 The Himalayan Community Carbon Project, was registered with the Government of Nepal REDD+ Cell in 2014 and was certified under Plan Vivo. No credits were ever issued from this project. Stevenson, C. \& M. Kunwar. 2017. Communication with Rights and Resources Initiative in December 2017.

46 Shahab, N. 2017a. Event Coverage: Indonesia not ready to bury REDD+. National Discussion finds emissionreducing scheme to be a work in progress. Forest News. Center for International Forestry Research. 23 October 2017.; Shahab, N. 2017b. Interview: Sharing the benefits of REDD+ in Indonesia - A Q \& A with CIFOR Scientist Shintia Arwda. Forest News. Center for International Forestry Research. 24 October 2017. 
${ }^{47}$ Forest Trends. 2017a. Fertile Ground - State of Forest Carbon finance 2017. Washington DC: Forest Trends.

${ }^{48}$ Andiko. 2017 - Unpublished. Legal Opinion - Legal Advice on Carbon Trading for Community Forests in Indonesia. ; Kusworo, A. 2017. Communication with Rights and Resources Initiative in December 2017. ; Pio, D. 2017. Communication with Rights and Resources Initiative in December 2017. ; Loft, L., Ravikumar, A., Gebara, M.F. Thuy Pham, T., Resosidarmo, I.A.P., Assembe, S., Tovar, J.G., Mwangi, E., and K. Andersson. 2015. Taking Stock of Carbon Rights in REDD+ Candidate Countries: Concept Meets Reality. Forests. 6: 1031-1060.

${ }^{49}$ Chomba, S. et al. 2016, Roots on inequity. How the Implementation of REDD+ reinforces past injustices. Land Use Policy. 50. 202-213.; Mwangi, E., Duporge, I, and K. Andersson. 2015. Can REDD+ shift the tide against elite capture of forest benefits? Probably not. Forest News. 25 August 2015. Bogor: Center for international Forestry Research.; CIFOR. 2014. What do you need to consider when thinking about policies for sharing benefits from REDD+?. Bogor: Center for International Forestry Research. Accessed, 12 December 2017. https://www.cifor.org/knowledge-tree/.

${ }^{50}$ Forest Trends 2017a. Fertile Ground - State of Forest Carbon finance 2017. Washington DC: Forest Trends. $p$ 53.

51 UN REDD \& FCPF. 2015. Joint FCPF/UN-REDD Programme Guidance Note for REDD+ Countries: Establishing and Strengthening Grievance Redress Mechanisms. p.3.

52 UN REDD \& FCPF. 2015. Joint FCPF/UN-REDD Programme Guidance Note for REDD+ Countries: Establishing and Strengthening Grievance Redress Mechanisms.

${ }^{53}$ Requirements 4.12-4.14. Plan Vivo. No date.

${ }^{54}$ VCS. 2015. Guidance for Jurisdictional and Nested REDD+ Program Design. V 3.0. Washington DC: Voluntary Carbon Standard.

${ }^{55}$ Gold Standard. 2017b. Annex B: Grievance Mechanism. Gold Standard for the Global Goals Land-use \& Forests Activity Requirements. Accessed 10 December 2017. https://globalgoals.goldstandard.org/200/201-lufgold-standard-for-the-global-goals-land-use-forests-activity-requirements\# Toc485820156.

56 VCS. 2017. VCS Standard Version 3.7. Requirements Document. 21 June 2017. Washington DC: Voluntary Carbon Standard. p. 24-25.

${ }^{57}$ Figure includes Nepal (Ambiguous) since the project was cancelled at the end of 2017. Due to a lack of consistent dis-aggregation by certifiers, these include both projects in the pipeline and those that are now operational. Based on data from Forest Trends' Ecosystem Marketplace. Drawing on findings from Gold Standard, Plan Vivo, Voluntary Carbon Standard, the American Carbon Registry, and Climate Action Reserve.

58 Based on data from Forest Trends' Ecosystem Marketplace. Drawing on findings from Gold Standard, Plan Vivo, Voluntary Carbon Standard, the American Carbon Registry, and Climate Action Reserve.

59 The Early Movers Program have signed an MOU with Mexico, which would make it 9 countries total. Forest Trends. 2017a. Fertile Ground - State of Forest Carbon finance 2017. Washington DC: Forest Trends.

${ }^{60}$ Forest Trends 2017a. Fertile Ground - State of Forest Carbon finance 2017. Washington DC: Forest Trends. p 38.

61 The Amazon Fund does not produce tradable offsets. Forest Trends 2017a. Fertile Ground - State of Forest Carbon finance 2017. Washington DC: Forest Trends.

${ }^{62}$ Cote D'Ivoire, Dominican Republic, Fiji, Madagascar, and Nicaragua not part of our sample. 
${ }^{63}$ Forest Trends 2017a. Fertile Ground - State of Forest Carbon finance 2017. Washington DC: Forest Trends.

${ }^{64}$ Zambia is the one country not in our sample.

${ }^{65}$ Forest Trends 2017a. Fertile Ground - State of Forest Carbon finance 2017. Washington DC: Forest Trends.

${ }^{66}$ See for example, RRI. 2016. Community Rights and Tenure in Country Emissions Reduction Programs. Rights and Resources Initiative, Washington, DC.; Gauthier, Marine (2018). Mai-Ndombé: Le laboratoire de la REDD+ beneficiera-t-il aux communités et autochtones? (Forthcoming). Rights and Resources Initiative: Washington D.C. 